\title{
PERAN MAINTENANCE DALAM MEMODERASI PENGARUH TQM TERHADAP KINERJA PERUSAHAAN BOUNTY CRUISES DI PELABUHAN BENOA
}

\author{
Ni Putu Tara Damayanti Dewi ${ }^{1}$ \\ Ni Ketut Purnawati
}

\author{
${ }^{12}$ Fakultas Ekonomi dan Bisnis Universitas Udayana, Bali, Indonesia \\ email: taradamayanti99@gmail.com ${ }^{1}$
}

\begin{abstract}
ABSTRAK
Kinerja Perusahaan merupakan suatu keadaan yang dihasilkan oleh suatu perusahaan dengan mengacu pada standar penilaian kinerja perusahaannya. Kinerja dijadikan sebagai bahan evaluasi bagi manajemen terhadap kualitas dan tinggi rendahnya kinerja organisasi. Dalam mengelola kualitas, perusahaan perlu menerapkan sistem manajemen kualitas yaitu Total Quality Management (TQM). Perusahaan juga perlu memperhatikan maintenance suatu objek layanan agar tetap berfungsi dengan baik. Penelitian ini bertujuan untuk mengetahui kinerja perusahaan yang dipengaruhi TQM dan peran maintenance dalam memperkuat atau memperlemah pengaruh TQM terhadap kinerja perusahaan. Penelitian ini menggunakan sampel jenuh sejumlah 96 orang crew/staff melalui metode wawancara dan kuisioner dengan teknik analisis data yang digunakan yaitu Analisis Faktor dan Moderated Regression Analysis (MRA). Penelitian ini menghasilkan adanya peran maintenance yang mampu memperkuat pengaruh TQM terhadap kinerja perusahaan. Hasil penelitian ini dapat menjadi pedoman bagi perusahaan melalui pelaksanaan maintenance dan dimensi kualitas.
\end{abstract}

Kata Kunci : TQM, Maintenance, Kinerja Perusahaan.

\begin{abstract}
Company performance is a condition produced by a company with reference to the company's performance appraisal standards. Performance is used as an evaluation material for management of the quality and level of organizational performance. In managing quality, companies need to implement a quality management system, namely Total Quality Management (TQM). Companies also need to pay attention to the maintenance of a service object in order to keep it functioning properly. This study aims to determine the performance of companies that are affected by TQM and the role of maintenance in strengthening or weakening the influence of TQM on company performance. This study used a saturated sample of $96 \mathrm{crew} /$ staff through interviews and questionnaires with the data analysis techniques used, namely Factor Analysis and Moderated Regression Analysis (MRA). This study results in a maintenance role that can strengthen the influence of TQM on company performance. The results of this study can guidelines through the implementation of maintenance and quality dimensions.
\end{abstract}

Keywords: TQM, Maintenance, Company Performance. 


\section{PENDAHULUAN}

Sektor jasa wisata bahari merupakan salah satu sektor yang memberikan dampak positif pada pertumbuhan pariwisata. Sektor jasa ini sangat beragam dan kompleks serta sangat dipengaruhi oleh perkembangan informasi dan teknologi. Sektor jasa ini memiliki karakteristik yang tidak beruwujud sehingga konsumen akan menilai mutu jasa tersebut baik atau buruk berdasarkan tempat, pelayanan, peralatan, komunikasi, serta harga. Peluang ini dapat menciptakan persaingan antar pebisnis dalam memperebutkan pasar. Perusahaan harus memiliki strategi khusus agar produk dan jasa yang ditawarkan memiliki keunggulan bersaing sehingga dapat meningkatkan kinerja perusahaan (Widjaya \& Suryawan, 2014).

Kinerja Perusahaan merupakan suatu keadaan yang dihasilkan oleh suatu perusahaan dengan mengacu pada standar penilaian kinerja yang diterapkan suatu perusahaan (Nawawi, 2006 :10). Penilaian dari kinerja ini dapat didasarkan atas: (1) kualitas, merupakan pengukuran untuk mengetahui sejauh mana karyawan dapat melaksanakan tugas dan tanggung jawab sesuai posisinya, (2) kuantitas, merupakan pengukuran kualitas terhadap jumlah produk yang dihasilkan sesuai dengan kemampuan karyawan, (3) ketepatan waktu, merupakan pengukuran dengan menggunakan waktu terhadap penyelesaian suatu aktivitas (Firmanzah et al., 2017) .

Penilaian kinerja yang efektif dalam jasa baik jasa transportasi ataupun jasa jenis lainnya dilakukan dengan menjadikan kepuasan konsumen sebagai fokus penilaiannya, salah satunya melalui penilaian terhadap kualitas jasa secara menyeluruh (Schepers \& Nijssen, 2018). Kualitas tersebut dapat ditunjukkan melalui berbagai dimensi salah satunya keandalan yaitu perusahaan hendaknya memberikan pelayanan secara tepat kepada konsumen dan tanggap melakukan perbaikan berkelanjutan terhadap kualitas layanan. Sistem yang tepat dalam melakukan perbaikan kualitas berkelanjutan yaitu sistem manajemen perusahaan dengan menerapkan alat manajemen kualitas yang disebut Total Quality Management (TQM).

Total Quality Management (TQM) merupakan suatu pendekatan dalam menjalankan usaha yang mencoba untuk memaksimumkan daya saing organisasi melalui perbaikan terus menerus atas produk, jasa, tenaga kerja, proses dan lingkungannya. Total Quality Management (TQM) sangat penting diterapkan untuk mengelola kualitas seluruh level operasi suatu perusahaan melalui penerapan fokus pada pelanggan, obsesi terhadap kualitas, kerjasama tim, pemberdayaan karyawan dan perbaikan berkelanjutan. Total Quality Management (TQM) digunakan untuk mengelola kualitas produk/layanan secara terus menerus merupakan salah satu langkah dalam mencapai tujuan. Akan lebih efektif ketika perusahaan juga memperhatikan pemeliharaan terhadap suatu objek layanan agar tetap berfungsi dengan baik. Dengan meningkatkan maintenance akan menjadi cara yang tepat untuk menempatkan kembali operasional sistem yang lebih cepat.

Maintenance dalam perusahaan jasa meliputi seluruh aktivitas yang terlibat dalam mempertahankan perlengkapan sistem agar berjalan dengan baik. Terdapat dua taktik maintenance yaitu meningkatkan pemeliharaan pencegahan (preventive maintenance) dan meningkatkan kecepatan dalam perbaikan yang mencangkup inspeksi rutin, pemberian layanan dan menjaga fasilitas agar tetap pada kondisi 
baik untuk mencegah kegagalan (Heizer Jay., 2015: 752). Meningkatkan manajemen pemeliharaan akan menjadi cara yang tepat untuk menempatkan kembali operasional sistem yang tepat.

Maintenance penting untuk dilakukan secara rutin khususnya pada bagian vital dan inti dari perusahaan yang bergerak di bidang transportasi wisata seperti Kapal Pesiar. Kapal tidak bisa berlayar apabila terjadi kerusakan di luar prediksi, hal ini akan berdampak pada buruknya citra perusahaan. Maintenance meliputi seluruh kegiatan yang berhubungan dengan memelihara peralatan dan sistem agar mampu berfungsi dengan baik sehingga, secara teoritis maintenance dapat menjamin operasional fasilitas yang memadai serta mendukung kemampuan mesin dalam memenuhi keselamatan serta kebutuhan aktivitas transportasi jasa (Pradnyandari, 2019). Oleh karena itu, maintenance juga dapat memperkuat atau memperlemah unsur TQM terhadap tingkat kinerja perusahaan.

Industri wisata hiburan dan rekreasi bahari merupakan salah satu industri yang akan terus berkembang khususnya wisata bahari yang terdapat di Bali. Salah satu sarana wisata hiburan dan rekreasi bahari yang menarik di Bali adalah Bounty Cruises. Bounty Cruises adalah perusahaan pertama yang memperkenalkan wisata bahari di Bali dengan armada utamanya MV. Bounty Cruises. Bounty Cruises memiliki layanan perjalanan wisata Day Cruises ke Nusa Lembongan serta Nusa Penida selain itu juga terdapat sunset dinner cruises yang merupakan aktivitas makan malam romantis di atas kapal pesiar Bounty Cruises dengan mengelilingi area pantai Tanjung Benoa. Dalam kurun waktu 2 tahun terakhir, jumlah penumpang mengalami penurunan yang berturut-turut dari 2017 hingga puncaknya di awal tahun 2020. Hal tersebut mengindikasikan bahwa adanya penurunan kinerja yang diakibatkan adanya penurunan jumlah wisatawan yang datang ke Bali sebesar 10 persen di tahun 2019 dan adanya peningkatan jumlah usaha transportasi air yang terdapat di pelabuhan Sanur yang merupakan salah satu faktor yang mengharuskan Bounty Cruises lebih meningkatkan layanannya.

Sejauh ini, dari akhir tahun 2016, adanya kenaikan sebesar 336,9 persen dari keseluruhan jumlah penumpang naik dari Pelabuhan Sanur, bila dibandingkan dengan akhir tahun 2015. Penumpang yang masuk melalui Pelabuhan Benoa terjadi penurunan sebesar 10,39 persen dibanding tahun 2015 menurut Statistik Transportasi Udara dan Laut Provinsi Bali, 2016. Penurunan penumpang yang masuk melalui Pelabuhan Benoa mrupakan salah satu hambatan bagi perusahaan sejenis di seputar Pelabuhan Benoa salah satunya Bounty Cruises sendiri. Jasa transportasi laut di bali sendiri saat ini cenderung menurun, hingga Maret 2020 telah terjadi penurunan pengunjung sebesar 61,91 persen (Statistik Transportasi Udara dan Laut Provinsi Bali, Maret, 2020). Penilaian kinerja perusahaan saat ini hanya pada pengukuran dari aspek keuangan dan dengan menggunakan guest review belum melakukan penilaian secara keseluruhan. Perusahaan belum menerapkan pedoman pengukuran yang pasti dalam melakukan penilaian terhadap kinerja dalam aspek non keuangan. Dengan begitu, perusahaan dalam memenuhi kebutuhan pelanggan jangka panjang belum diperhatikan dengan jelas baik dalam pengembangan maupun pelatihan kepada karyawan, menjaga kepuasan pelanggan 
terhadap pemberian jasa. Berdasarkan keadaan tersebut tentu akan mempengaruhi perkembangan bisnis perusahaan.

Studi empiris terkait dengan pengaruh TQM terhadap kinerja perusahaan telah banyak dilakukan. Terdapat beberapa hasil penelitian (Al-Damen, 2017) yang menyatakan bahwa TQM memiliki pengaruh positif terhadap kinerja organisasi jasa di Jordan. Penelitian lainnya menyimpulkan bahwa elemen TQM yaitu fokus pelanggan, perbaikan berkelanjutan, strategis, dan keterlibatan total karyawan memiliki hubungan yang positif dan signifikan terhadap kinerja organisasi sektor jasa pelayanan (Bouranta et al., 2019; Efendi \& Mandala, 2018; Pambreni et al., 2019). Pernyataan tersebut berbeda dengan penelitian (Reynaldo \& Pondang, 2018) yang menyimpulkan bahwa fokus pada pelanggan dan perbaikan secara berkesinambungan tidak memiliki pengaruh yang signifikan terhadap kinerja manajerial transportasi udara. Penelitian lainnya menyimpulkan bahwa pemeliharaan yang sistematis untuk infrastruktur diperlukan untuk menganalisis perbaikan transportasi berkelanjutan dan harus diprioritaskan dalam meningkatkan operasional suatu perusahaan (Famurewa et al., 2015; Gaudry et al., 2016; Husna, 2015).

Berdasarkan pada kondisi diatas maka perlu dijelaskan pengaruh dimensi dari TQM terhadap kinerja perusahaan dengan adanya variabel maintenance yang dapat memoderasi dengan peranan memperkuat ataupun memperlemah pengaruh tersebut. Perusahaan perlu melakukan evaluasi berkelanjutan dalam meningkatkan kualitas agar perusahaan dapat terus bersaing secara kompetitif dengan kompetitor lainnya.

Kinerja merupakan output dari suatu kegiatan manajemen suatu perusahaan yang dihasilkan baik melalui kualitas maupun kuantitas yang dicapai oleh seseorang dalam mempertanggung jawabkan tugas yang diberikan. Menurut Handoko (2002:9) istilah kinerja sering digunakan untuk mengistilahkan prestasi kinerja pegawai atau tingkat keberhasilan dapat diukur melalui kesuksesan individu ataupun kelompok individu dalam suatu perusahaan. Berdasarkan pernyataan di atas, dapat disimpulkan bahwa kinerja perusahaan jasa adalah suatu kegiatan manajemen yang dilakukan oleh individu atau kelompok individu yang memiliki tanggung jawab dalam suatu perusahaan dibidang pelayanan pada kualitas dan kuantitas yang kemudian dapat dikonsumsi dan diproduksi secara bersamaan setelah jasa tersebut diberikan kepada pelanggan.

Kinerja dianggap sebagai hasil kerja yang dicapai seseorang dalam melaksanakan tugas-tugas yang dibebankan kepadanya didasarkan atas kecakapan, pengalaman kesungguhan, serta waktu (Suartina, 2019). Peningkatan kinerja suatu perusahaan biasanya akan berdampak pada peningkatan kinerja keuangan sehingga biasanya pengukuran kinerja perusahaan berupa perhitungan analisis aspek keuangan. Namun, penilaian berdasarkan analisis aspek keuangan bisa saja menjadi bias karena kinerja keuangan yang baik pada suatu periode dapat dicapai dengan mengorbankan kepentingan jangka panjang perusahaan. Sebaliknya, kinerja perusahaan kurang baik dalam jangka pendek karena perusahaan melakukan investasi demi kepentingan jangka panjang. Maka diperlukannya penilaian aspek non finansial seperti perspektif proses bisnis 
internal, perspektif pelanggan dan perspektif pembelajaran salah satunya adalah aspek kualitas.

Peningkatan kualitas menjadi titik fokus setiap perusahaan dalam menghadapi persaingan. Berbagai cara diterapkan guna meningkatkan kualitas yang dilakukan baik terhadap produk/barang, fasilitas pelayanan dan manajemen pada perusahaan. Semakin berkembangnya ilmu pengetahuan, lahirlah suatu inovasi yang mudah dipahami yaitu Total Quality Management (TQM). Total Quality Management (TQM) memiliki sepuluh dimensi dalam penerapannya yaitu; Fokus pada pelanggan, Obsesi terhadap kualitas, Pendekatan ilmiah, Komitmen jangka panjang, Kerjasama tim, Perbaikan berkesinambungan, pendidikan dan pelatihan, kebebasan terkendali, kesatuan tujuan, dan adanya keterlibatan dan pemberdayaan karyawan. (Pambreni et al., 2019). Namun, ada pula yang menyatakan bahwa bahwa fokus pada pelanggan dan perbaikan secara berkesinambungan tidak memiliki pengaruh yang signifikan terhadap kinerja manajerial transportasi jasa (Reynaldo \& Pondang, 2018).

Tujuan Total Quality Management (TQM) yaitu menghasilkan produk atau jasa yang berkualitas. Dasar pemikiran suatu perusahaan dalam menerapkan TQM agar perusahaan mampu bersaing dan mengungguli pasar global dengan memberikan kualitas terbaik. Dalam menghasilkan kualitas terbaik, diperlukannya upaya perbaikan secara berkesinambungan terhadap kemampuan sumber daya yang dimiliki. Hal tersebut dapat meningkatkan kemampuan perusahaan untuk menyelenggarakan pelayanan secara kompetitif, efisien dan efektif. Manfaat Total Quality Management (TQM) adalah meningkatkan kualitas dan kinerja manajerial dalam mengelola perusahaan agar mampu menghasilkan keuntungan bagi perusahaan. Perusahaan melakukan perbaikan secara berkesinambungan ditujukan untuk menciptakan kepuasan pelanggan dan meningkatkan citra perusahaan di mata pelanggan serta mengurangi berbagai bentuk pemborosan. Perusahaan dapat menjadi leader di antara pasar sejenis, mampu menciptakan kerja sama tim, membuat perusahaan lebih mengutamakan harapan pelanggan dan membuat perusahaan lebih mudah beradaptasi terhadap pelanggan.

Pemeliharaan (maintenance) memuat seluruh kegiatan yang berkaitan dengan menjaga seluruh peralatan sistem agar dapat bekerja dengan baik sebagaimana mestinya (Heizer dan Render, 2015:752). Pemeliharaan secara umum bertujuan untuk memfokuskan dalam hal pencegahan untuk mengurangi ataupun menghindari kerusakan dari peralatan dengan memastikan tingkat keandalan dan kesiapan serta berguna dalam meminimalkan biaya perawatan. Pemeliharaan yang sistematis untuk infrastruktur diperlukan untuk menganalisis perbaikan transportasi berkelanjutan dan harus diprioritaskan dalam meningkatkan operasional suatu perusahaan dan berguna untuk mendukung pengambilan keputusan oleh staff yang berwenang (Famurewa et al., 2015) dan (Gaudry et al., 2016).

Total Quality Management (TQM) berpengaruh positif terhadap kinerja perusahaan, hipotesis pertama ini memperhatikan adanya hubungan secara teoritis maupun penelitian sebelumnya. Dengan menerapkan TQM, perusahaan mencoba meningkatkan daya saing melalui perbaikan secara terus menerus terhadap produk, tenaga kerja, proses dan lingkungannya (Jannah et al., 2017). Perusahaan 
yang menggunakan TQM mampu mengurangi biaya operasi dan meningkatkan penghasilan sehingga laba semakin meningkat. Penelitian sebelumnya menemukan bahwa pentingnya pemberdayaan karyawan sangat mempengaruhi kinerja manajerial suatu perusahaan dan mampu meningkatkan kepuasan pelanggan dari sisi fasilitas, kualitas layanan dan informasi aksesibilitas secara gabungan sebagai dampak penerapan Total Quality Management (Yuliana dina, 2017). Penelitian serupa dijelaskan lebih lanjut oleh Palandeng et al. (2017) yang menyatakan bahwa unsur-unsur TQM dapat meningkatkan kinerja perusahaan. Hasil penelitian tersebut juga didukung oleh penelitian dari (Bouranta et al., 2019; Efendi \& Mandala, 2018; Pambreni et al., 2019) yang menyatakan bahwa fokus pada pelanggan, perbaikan berkesinambungan, dan keterlibatan karyawan menunjukkan dampak positif Total Quality Management pada kinerja organisasi. Dalam meningkatkan efektivitas kinerja, perusahaan hendaknya dilakukan perbaikan secara berkesinambungan agar penilaian konsumen terhadap perusahaan tidak memburuk. Melalui penelitian terdahulu dan kajian secara teoritis, dapat ditarik hipotesis sebagai berikut.

$\mathrm{H}_{1}: T Q M$ berpengaruh positif terhadap kinerja perusahaan.

Maintenance mampu berperan dalam memoderasi pengaruh TQM terhadap kinerja perusahaan yang mana hipotesis kedua ini memperhatikan hubungan teoritis yaitu adanya penelitian terdahulu yang sejalan dengan pernyataan Apabila maintenance berjalan dengan baik dengan selalu mengadakan perbaikan secara berkesinambungan, maka fokus pada pelanggan dapat tercapai, pelanggan mendapatkan kualitas yang diharapkan, tim dapat bekerja sesuai dengan pembagian tugas serta meningkatkan efektivitas manajemen yang juga menyebutkan adanya pengaruh yang kuat antara maintenance dengan kinerja operasional pemeliharaan (Modgil \& Sharma, 2016). Penelitian (Gaudry et al., 2016) juga mendukung adanya optimalisasi maintenance terhadap infrastruktur transportasi yang tentunya dalam perbaikan dan pemeliharaan dikerjakan secara profesional oleh staff pemeliharaan teknis secara berkesinambungan untuk meningkatkan kinerja perusahaan.

Dengan adanya keterkaitan antara maintenance dengan dimensi Total Quality Management, maintenance dapat diaplikasikan sebagai variabel yang memoderasi Total Quality Management. Terdapat penelitian lain yang memperkuat argumen tersebut yaitu penelitian yang dilakukan oleh (Au-Yong et al., 2017) yaitu tentang adanya keterkaitan maintenance terhadap kinerja perusahaan yang dilihat dari pemberdayaan karyawan yang dapat memperkuat atau memperlemah TQM. Penelitian dari (Famurewa et al., 2015) juga mendukung adanya analisis pemeliharaan yang sistematis dalam meningkatkan operasional perusahaan. Hal ini mengindikasikan bahwa terdapat pengaruh maintenance yang dapat memoderasi pengaruh unsur-unsur Total Quality Management terhadap kinerja perusahaan. Maka dapat disimpulkan bahwa dari hasil penelitian-penelitian di atas menunjukkan adanya keterkaitan unsur-unsur TQM yang dapat meningkatkan kinerja perusahaan apabila unsur-unsur TQM dapat berfungsi dengan efektif. Keefektifan penggunaan unsur TQM tentunya memerlukan kegiatan yang disebut dengan pemeliharaan. Berdasarkan kajian teoritis tersebut, dapat ditarik hipotesis sebagai berikut: 
$\mathrm{H}_{2}$ : Maintenance memperkuat pengaruh TQM terhadap kinerja perusahaan.

Berikut ini adalah kerangka konseptual yang menjelaskan hubungan dari variabel-variabel diatas seperti pada Gambar 1.

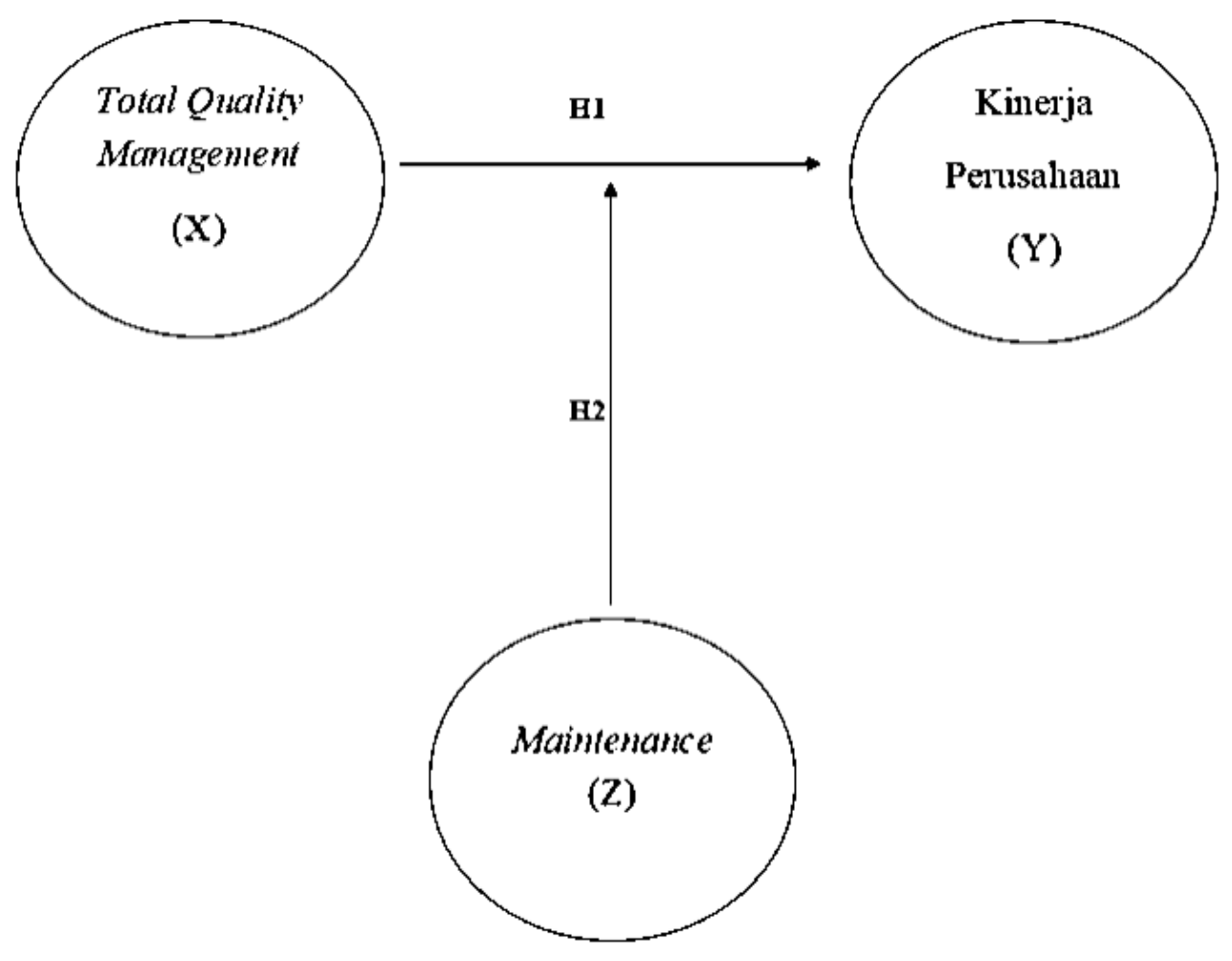

Gambar 1. Kerangka Konseptual

Model tersebut menyatakan bahwa terdapat pengaruh Total Quality Manajement terhadap Kinerja Perusahaan $\left(\mathrm{H}_{1}\right)$. Maintenance sebagai variabel moderator dapat memperkuat atau memperlemah hubungan antara TQM dengan kinerja perusahaan $\left(\mathrm{H}_{2}\right)$.

\section{METODE PENELITIAN}

Penelitian ini adalah penelitian asosiatif menggunakan pendekatan kuantitatif yang mengindikasikan terdapat atau tidaknya hubungan kehandalan perusahaan terhadap maintenance (pemeliharaan peralatan/mesin yang berkaitan pada aktivitas pelayaran) dengan kemampuan perusahaan dalam hal menerapkan dimensi Total Quality Management (TQM) yang kemudian dapat mempengaruhi kinerja perusahaan Bounty Cruises di Pelabuhan Benoa.

Populasi terdiri dari obyek/subyek memiliki karakteristik dan kuantitas tertentu yang ditetapkan oleh peneliti yang kemudian di tarik kesimpulannya (Sugiono, 2017:443). Populasi dalam penelitian ini adalah seluruh karyawan tetap atau staff/crew/engineering Bounty Cruises tahun 2019 yang jumlah keseluruhannya sebanyak 96 orang. Pada penelitian ini seluruh populasi diteliti (sensus). Data penelitian ini diperoleh dengan melakukan wawancara dan 
angket/kuesioner kepada responden (karyawan/staff/ crew) dan wawancara dengan pihak pimpinan.

Data yang diperoleh dianalisis dengan menggunakan Analisis faktor yang kemudian hasil faktor baru akan dianalisis kembali dengan menggunakan Moderated Regression Analysis (MRA). Analisis faktor dalam pengelolaannya menemukan hubungan antara sejumlah variabel yang saling tidak terikat satu dengan lain sehingga dapat dibuat satu ataupun beberapa kumpulan variabel yang lebih sedikit dari jumlah variabel awal. Jadi, analisis faktor digunakan untuk memperoleh skor faktor dari 5 dimensi TQM yaitu fokus pada pelanggan, obsesi pada kualitas, perbaikan berkesinambungan, kerjasama tim dan pemberdayaan karyawan. Menurut Suyana Utama (2016:199) Validitas dalam analisis faktor adalah dengan melihat besarnya nilai-nilai pada tabel:

Tabel 1.

Nilai Validitas dalam Analisis Faktor

\begin{tabular}{|c|c|}
\hline Nilai Validitas & Cut-off Value \\
\hline KMO (Kaiser-Meyen-Olkin) & $\geq 0,50$ \\
\hline$X^{2}$ (Chi Square) & $\overline{\text { Diharapkan besar }}$ \\
\hline Significance Probability & $<0,50$ \\
\hline Eigen Value & $>1,00$ \\
\hline Varians Kumulatif & $\geq 60$ persen \\
\hline Anti-Image & $\geq 0,50$ \\
\hline
\end{tabular}

Sumber: Suyana Utama (2016)

Moderated Regression Analysis (MRA) atau uji interaksi merupakan aplikasi khusus regresi berganda linear yang dalam persamaan regresinya mengandung unsur interaksi antara satu atau lebih variabel independen terhadap variabel dependen. Untuk menguji pengaruh penerapan TQM (X) terhadap Kinerja Perusahaan (Y) yang dimoderasi oleh Maitenance digunakan Moderated Regression Analysis (MRA). Moderated Regression Analysis menggunakan pendekatan analitik untuk mengelola pengaruh variabel moderator (Ghozali, 2016). Dalam menggunakan MRA dengan adanya satu variabel predictor (X), rumus yang diterapkan, yaitu Ghozali (2016:219):

$$
\boldsymbol{Y}=\boldsymbol{\alpha}+\boldsymbol{\beta}_{1} \boldsymbol{X}_{i}+\boldsymbol{\beta}_{2} \boldsymbol{Z}_{i}+\boldsymbol{\beta}_{3}\left(\boldsymbol{X}_{i} Z_{i}\right)+\boldsymbol{\varepsilon}
$$

Keterangan :

$\begin{array}{ll}\mathrm{Y} & =\text { Kinerja Perusahaan } \\ \alpha & =\text { Konstanta } \\ \beta 1, \beta 2, \beta 3 & =\text { Koefisien Regresi } \\ \mathrm{Xi} & =\text { Total Quality Management } \\ \mathrm{Zi} & =\text { Maintenance } \\ \mathrm{XiZi} & =\text { Interaksi TQM dengan Maintenance } \\ \varepsilon & =\text { Standar Error }\end{array}$


Hipotesis dalam penelitian diterima jika koefisien interaksi (XiZi) positif dan lebih kecil dari $\alpha=0,05$. Menurut (Pradnyandari, 2019) terdapat jenis-jenis moderasi yang dilihat dari interaksi antar variabel yaitu:

\section{Tabel 2.}

\begin{tabular}{|c|c|c|}
\hline \multicolumn{3}{|c|}{ Jenis Peran Moderasi } \\
\hline $\begin{array}{c}\text { No. } \\
1\end{array}$ & $\begin{array}{c}\text { Hasil Uji } \\
\beta 2 \text { non significant } \\
\beta 3 \text { significant }\end{array}$ & $\begin{array}{c}\text { Jenis Moderasi } \\
\text { Moderasi murni (pure moderator) }\end{array}$ \\
\hline 2 & $\begin{array}{l}\beta 2 \text { significant } \\
\beta 3 \text { significant }\end{array}$ & $\begin{array}{l}\text { Moderasi semu (quasi moderator) yaitu merupakan } \\
\text { variabel yang memoderasi hubungan antara variabel } \\
\text { independen dengan variabel dependen yang sekaligus } \\
\text { menjadi variabel independen. }\end{array}$ \\
\hline 3 & $\begin{array}{l}\beta 2 \text { significant } \\
\beta 3 \text { non significant }\end{array}$ & $\begin{array}{l}\text { Predikator moderasi (predicator moderation variable), } \\
\text { yaitu variabel moderasi hanya berperan sebagai } \\
\text { predikator (independen), dan bukan memoderasi dalam } \\
\text { model hubungan yang dibentuk. }\end{array}$ \\
\hline 4 & $\begin{array}{l}\beta 2 \text { non significant } \\
\beta 3 \text { non significant }\end{array}$ & $\begin{array}{l}\text { Moderasi potensial (homologiser moderator), yaitu } \\
\text { variabel tersebut potensial menjadi variabel moderasi. }\end{array}$ \\
\hline
\end{tabular}

Koefisien variabel moderasi menjabarkan peran dari variabel $\mathrm{Z}$ pada variabel bebas $(\mathrm{X})$ terhadap variabel terikat $(\mathrm{Y})$ dengan peran mampu memperkuat ataupun memperlemah. Terdapat beberapa penjelasan dengan melihat koefisien $\beta 1$ dan $\beta 3$ (Pradnyandari, 2019). Apabila $\beta 1$ adalah positif dengan tingkat signifikan atau tidak, dan $\beta 3$ positif signifikan, dengan begitu $Z$ variabel moderasi mampu memperkuat variabel X terhadap Y. Apabila $\beta 1$ adalah negatif dengan tingkat signifikan atau tidak, dan $\beta 3$ negatif signifikan, dengan begitu $\mathrm{Z}$ variabel moderasi mampu memperkuat pengaruh $\mathrm{X}$ terhadap $\mathrm{Y}$. Apabila $\beta 1$ positif dengan tingkat signifikan atau tidak, dan $\beta 3$ negatif signifikan, dengan begitu $\mathrm{Z}$ sebagai variabel moderasi dengan peran memperlemah pengaruh $\mathrm{X}$ terhadap Y. Apabila $\beta 1$ negatif dengan tingkat signifikan atau tidak, dan $\beta 3$ positif signifikan, dengan begitu $\mathrm{Z}$ sebagai variabel moderasi yang berperan memperlemah adanya pengaruh $\mathrm{X}$ padaY.

\section{HASIL DAN PEMBAHASAN}

Pengujian validitas dilakukan untuk memeriksa pengukuran indikator yang terdapat dalam instrumen penelitian yang berupa kuisioner. Setiap instrumen dinyatakan valid apabila nilai koefisien korelasi $\geq 0,30$ yang merupakan nilai pembanding minimal untuk mendapatkan korelasi yang valid. Berikut hasil uji validitas pada Tabel 3 .

Tabel 3. Hasil Uji Validitas

\begin{tabular}{ccclcc}
\hline No & Variabel & & \multicolumn{1}{c}{ Indikator } & $\begin{array}{c}\text { Koefisien } \\
\text { Korelasi }\end{array}$ & Keterangan \\
\hline 1 & $\begin{array}{c}\text { Fokus pada } \\
\text { Pelanggan (X1) }\end{array}$ & $\mathrm{X} 1.1$ & $\begin{array}{l}\text { Interaksi saat melayani } \\
\text { pelanggan. }\end{array}$ & 0,767 & Valid \\
\hline Bersambung... & & & & \\
\end{tabular}


Ni Putu Tara Damayanti Dewi, Peran Maintenance Dalam...

Lanjutan Tabel 3.

\begin{tabular}{|c|c|c|c|c|c|}
\hline \multirow[t]{5}{*}{ No } & \multirow[t]{5}{*}{ Variabel } & \multicolumn{2}{|r|}{ Indikator } & \multirow{2}{*}{$\begin{array}{c}\begin{array}{c}\text { Koefisien } \\
\text { Korelasi }\end{array} \\
0,831\end{array}$} & \multirow{2}{*}{$\begin{array}{c}\text { Keterangan } \\
\text { Valid }\end{array}$} \\
\hline & & $\mathrm{X} 1.2$ & $\begin{array}{l}\text { Memberikan informasi } \\
\text { akurat. }\end{array}$ & & \\
\hline & & $\mathrm{X} 1.3$ & $\begin{array}{l}\text { Melayani pertanyaan } \\
\text { pelanggan. }\end{array}$ & 0,891 & Valid \\
\hline & & X1.4 & $\begin{array}{l}\text { Masukan evaluasi } \\
\text { pelanggan. }\end{array}$ & 0,879 & Valid \\
\hline & & $\mathrm{X} 1.5$ & $\begin{array}{l}\text { Kebijakan terhadap } \\
\text { konsumen. }\end{array}$ & 0,920 & Valid \\
\hline \multirow[t]{5}{*}{2} & \multirow[t]{5}{*}{$\begin{array}{l}\text { Obsesi pada } \\
\text { Kualitas (X2) }\end{array}$} & $\mathrm{X} 2.1$ & $\begin{array}{l}\text { Kualitas pelayanan yang } \\
\text { diberikan. }\end{array}$ & 0,850 & Valid \\
\hline & & $\mathrm{X} 2.2$ & $\begin{array}{l}\text { Ketepatan waktu } \\
\text { penyelesaian masalah. }\end{array}$ & 0,812 & Valid \\
\hline & & $\mathrm{X} 2.3$ & $\begin{array}{l}\text { Ketanggapan melayani } \\
\text { konsumen. }\end{array}$ & 0,900 & Valid \\
\hline & & $\mathrm{X} 2.4$ & $\begin{array}{l}\text { Evaluasi pelayanan setiap } \\
\text { periode. }\end{array}$ & 0,891 & Valid \\
\hline & & $\mathrm{X} 2.5$ & $\begin{array}{l}\text { Memperbaharui fasilitas tiap } \\
\text { periode. }\end{array}$ & 0,905 & Valid \\
\hline \multirow[t]{5}{*}{3} & \multirow{5}{*}{$\begin{array}{l}\text { Kerjasama } \\
\text { Tim (X3) }\end{array}$} & $\mathrm{X} 3.1$ & Kerjasama antar divisi kerja. & 0,901 & Valid \\
\hline & & $\mathrm{X} 3.2$ & $\begin{array}{l}\text { Adanya keakraban antar } \\
\text { karyawan. }\end{array}$ & 0,852 & Valid \\
\hline & & $\mathrm{X} 3.3$ & Tanggung jawab kerja. & 0,809 & Valid \\
\hline & & $\mathrm{X} 3.4$ & Komunikasi antar karyawan. & 0,798 & Valid \\
\hline & & $\mathrm{X} 3.5$ & Motivasi kerja karyawan. & 0,739 & Valid \\
\hline \multirow[t]{6}{*}{4} & \multirow{6}{*}{$\begin{array}{c}\text { Pemberdayaan } \\
\text { Berkelanjutan } \\
\text { (X4) }\end{array}$} & $\mathrm{X} 4.1$ & Desire. & 0,895 & Valid \\
\hline & & $\mathrm{X} 4.2$ & Trust. & 0,899 & Valid \\
\hline & & $\mathrm{X} 4.3$ & Confident. & 0,872 & Valid \\
\hline & & $\mathrm{X} 4.4$ & Credibility. & 0,950 & Valid \\
\hline & & $\mathrm{X} 4.5$ & Accountability. & 0,807 & Valid \\
\hline & & $\mathrm{X} 4.6$ & Communication. & 0,915 & Valid \\
\hline \multirow[t]{5}{*}{5} & \multirow{5}{*}{$\begin{array}{c}\text { Perbaikan } \\
\text { Berkelanjutan } \\
\text { (X5) }\end{array}$} & $\mathrm{X} 5.1$ & Komunikasi. & 0,857 & Valid \\
\hline & & $\mathrm{X} 5.2$ & Pembaharuan. & 0,752 & Valid \\
\hline & & $\mathrm{X} 5.3$ & Menrapikan masalah nyata. & 0,736 & Valid \\
\hline & & $\mathrm{X} 5.4$ & Dokumentasi perbaikan. & 0,869 & Valid \\
\hline & & $\mathrm{X} 5.5$ & $\begin{array}{l}\text { Memantau perubahan } \\
\text { masalah. }\end{array}$ & 0,812 & Valid \\
\hline \multirow[t]{5}{*}{6} & \multirow{5}{*}{$\begin{array}{l}\text { Maintenance } \\
\text { (Z) }\end{array}$} & $\mathrm{Z} 1.1$ & Pengecekan mesin. & 0,697 & Valid \\
\hline & & $\mathrm{Z} 2.2$ & $\begin{array}{l}\text { Pemeliharaan sistem dan } \\
\text { mesin. }\end{array}$ & 0,784 & Valid \\
\hline & & $\mathrm{Z} 3.3$ & Alokasi biaya pemeliharaan. & 0,717 & Valid \\
\hline & & Z4.4 & $\begin{array}{l}\text { Pengaruh pada kepuasan } \\
\text { pelanggan }\end{array}$ & 0,618 & Valid \\
\hline & & Z5.5 & $\begin{array}{l}\text { Pembelajaran dan } \\
\text { pertumbuhan. }\end{array}$ & 0,714 & Valid \\
\hline
\end{tabular}

Bersambung ... 
Lanjutan Tabel 3.

\begin{tabular}{|c|c|c|c|c|c|}
\hline No & Variabel & & Indikator & $\begin{array}{c}\text { Koefisien } \\
\text { Korelasi }\end{array}$ & $\begin{array}{c}\text { Keteranga } \\
n\end{array}$ \\
\hline & & Z6.6 & $\begin{array}{l}\text { Kesehatan, keamanan, } \\
\text { perlindungan dan } \\
\text { lingkungan. }\end{array}$ & 0,857 & Valid \\
\hline & & Z7.7 & Kepuasan pekerja & 0,698 & Valid \\
\hline \multirow[t]{9}{*}{7} & \multirow{9}{*}{$\begin{array}{c}\text { Kinerja } \\
\text { Perusahaan } \\
\text { (Y) }\end{array}$} & Y1.1 & $\begin{array}{l}\text { Pemberian layanan cepat } \\
\text { dan tepat. }\end{array}$ & 0,794 & Valid \\
\hline & & $\mathrm{Y} 1.2$ & $\begin{array}{l}\text { Tenaga kerja sesuai } \\
\text { kebutuhan. }\end{array}$ & 0,695 & Valid \\
\hline & & Y1.3 & $\begin{array}{l}\text { Modal Usaha dikelola } \\
\text { dengan efektif. }\end{array}$ & 0,885 & Valid \\
\hline & & Y1.4 & $\begin{array}{l}\text { Program promosi yang } \\
\text { efektif. }\end{array}$ & 0,891 & Valid \\
\hline & & Y1.5 & $\begin{array}{l}\text { Penilaian kinerja tepat } \\
\text { waktu. }\end{array}$ & 0,897 & Valid \\
\hline & & Y1.6 & Produktivitas karyawan. & 0,859 & Valid \\
\hline & & Y1.7 & Sumber daya efisien. & 0,936 & Valid \\
\hline & & $\mathrm{Y} 1.8$ & $\begin{array}{l}\text { Melaksanakan budaya } \\
\text { perusahaan. }\end{array}$ & 0,790 & Valid \\
\hline & & Y1.9 & $\begin{array}{l}\text { Melaksanakan visi misi } \\
\text { perusahaan. }\end{array}$ & 0,887 & Valid \\
\hline
\end{tabular}

Sumber: Data Diolah, 2020

Tabel 3. menunjukkan bahwa seluruh butir pernyataan dalam instrument penelitian tersebut valid dan layak untuk digunakan sebagai instrumen penelitian yang memiliki nilai koefisien korelasi dengan skor total seluruh item pernyataan yang lebih besar dari $r$ tabel $(0,30)$.

Uji realibilitas dilakukan untuk menunjukkan adanya konsistensi alat ukur dalam penggunaannya, dapat dikatakan reliabel jika responden terhadap pertanyaan konsisten untuk mengukur obyek yang sama, maka akan menghasilkan data yang sama. Pengujian dilakukan dengan melihat koefisien cronbach alpha melebihi 0,6. Hasil uji reliabilitas ditujukan pada Tabel 4.

Tabel 4.

Hasil Uji Reliabilitas

\begin{tabular}{clcc}
\hline No. & \multicolumn{1}{c}{ Variabel } & Cronbach's Alpha & Keterangan \\
\hline $\mathbf{1}$ & Fokus pada Pelanggan $\left(\mathrm{X}_{1}\right)$ & 0,909 & Reliabel \\
$\mathbf{2}$ & Obsesi pada Kualitas $\left(\mathrm{X}_{2}\right)$ & 0,917 & Reliabel \\
$\mathbf{3}$ & Kerjasama Tim $\left(\mathrm{X}_{3}\right)$ & 0,874 & Reliabel \\
$\mathbf{4}$ & Pemberdayaan Karyawan $\left(\mathrm{X}_{4}\right)$ & 0,946 & Reliabel \\
$\mathbf{5}$ & Perbaikan Berkelanjutan $\left(\mathrm{X}_{5}\right)$ & 0,855 & Reliabel \\
$\mathbf{6}$ & Maintenance $(\mathrm{Z})$ & 0,850 & Reliabel \\
$\mathbf{7}$ & Kinerja Perusahaan $(\mathrm{Y})$ & 0,950 & Reliabel \\
\hline
\end{tabular}

Sumber: Data Diolah, 2018 
Analisis faktor yang dilakukan dalam penelitian ini bertujuan untuk memperoleh skor faktor dari variabel fokus pada pelanggan, obsesi pada kualitas, kerjasama tim, pemberdayaan karyawan dan perbaikan berkelanjutan guna melihat skor faktor dan mengeliminasi pernyataan tidak sesuai dengan loading faktor yang akan di regresikan dalam analisis regresi moderasi (MRA). Hasil Nilai Loading Factor akan didapatkan setelah penentuan jumlah faktor yang dapat dilihat dalam Tabel 5.

Tabel 5.

Total Variance Explained

\begin{tabular}{|c|c|c|c|c|c|c|}
\hline \multirow[t]{2}{*}{ Faktor } & \multicolumn{3}{|c|}{ Initial Eigenvalues } & \multicolumn{3}{|c|}{ Extraction Sums of Squared Loadings } \\
\hline & Total & $\%$ of Variance & Comulative \% & Total & $\%$ of Variance & $\begin{array}{c}\text { Cumulati } \\
\text { ve } \%\end{array}$ \\
\hline 1 & 2,134 & 42,679 & 42,679 & 2,134 & 42,679 & 42,679 \\
\hline 2 & 1,227 & 24,544 & 67,223 & 1,227 & 24,544 & 67,223 \\
\hline 3 & 0,835 & 16,710 & 83,933 & & & \\
\hline 4 & 0,625 & 12,494 & 96,427 & & & \\
\hline 5 & 0,179 & 3,573 & 100,000 & & & \\
\hline
\end{tabular}

Faktor yang memiliki nilai eigen lebih dari 1 akan dipertahankan dan faktor yang memiliki nilai eigen kurang dari 1 tidak akan diikutsertakan dalam model. Dari Tabel 5 diperoleh nilai eigen yang lebih besar dari 1 pada 1 faktor dan 2 faktor sehingga diperoleh jumlah faktor yang digunakan adalah 2 faktor. Selain hasil nilai konstruk, perlu diperhatikan faktor muatan atau loading factor dari tiaptiap indikator sebagai suatu syarat pemenuhan bahwa indikator yang digunakan sebagai pembentuk Total Quality Management adalah layak ataupun memenuhi syarat sebagai variabel pembentuk, hasil nilai loading factor terdapat dalam Tabel 6.

Tabel 6.

Hasil Nilai Loading Faktor

\begin{tabular}{llcccl}
\hline No & \multicolumn{1}{c}{$\begin{array}{c}\text { Dimensi Total Quality } \\
\text { Management }(\mathbf{X})\end{array}$} & $\begin{array}{c}\text { Nilai } \\
\text { Loading } \\
\text { Factor 1 }\end{array}$ & $\begin{array}{c}\text { Nilai } \\
\text { Loading } \\
\text { Factor2 }\end{array}$ & $\begin{array}{c}\text { Pedoman } \\
\text { Nilai }\end{array}$ & Simpulan \\
\hline $\mathbf{1}$ & Fokus Pada Pelanggan & $\mathbf{0 , 9 2 9}$ & 0,020 & 0,65 & $\begin{array}{l}\text { Memenuhi } \\
\text { Faktor 1 }\end{array}$ \\
$\mathbf{2}$ & Obsesi pada Kualitas & 0,365 & $\mathbf{0 , 6 9 0}$ & 0,65 & $\begin{array}{l}\text { Memenuhi } \\
\text { Faktor 2 }\end{array}$ \\
$\mathbf{3}$ & Kerjasama Tim & $-0,276$ & $\mathbf{0 , 8 1 8}$ & 0,65 & $\begin{array}{l}\text { Memenuhi } \\
\text { Faktor 2 }\end{array}$ \\
$\mathbf{4}$ & Pemberdayaan Karyawan & $\mathbf{0 , 9 1 2}$ & 0,70 & 0,65 & $\begin{array}{l}\text { Memenuhi } \\
\text { Faktor 1 } \\
\text { Tidak } \\
\text { Memenuhi }\end{array}$ \\
\hline
\end{tabular}

Sumber: Data diolah,2020

Berdasarkan Tabel 6. diketahui bahwa pedoman nilai loading factor adalah sebesar 0,65. Dari 5 variabel, terdapat 4 faktor yang tinggi pada salah satu faktor 
dan memiliki loading factor yang cukup kecil untuk faktor-faktor lainnya. Nilai loading factor untuk masing-masing dimensi Total Quality Management yaitu indikator fokus pada pelanggan memiliki nilai loading factor tertinggi pada faktor 1 yaitu 0,929 dan variabel pemberdayaan masyarakat yaitu 0,912 . Sedangkan nilai loading factor dengan faktor 2 sangat kecil, sehingga variabel ini dimasukkan dalam faktor 1. Untuk variabel Obsesi terhadap kualitas, kerjasama tim, dan perbaikan berkelanjutan memiliki nilai factor loading tertinggi pada faktor 2 yaitu obsesi terhadap kualitas yaitu 0,690 , kerjasama tim sebesar 0,818 , dan perbaikan berkelanjutan sebesar 0,399. Variabel perbaikan berkelanjutan tidak diikutsertakan dalam pengelompokan karena nilai loading factor lebih kecil dari 0,65 . Setelah terbentuk faktor yang masing-masing beranggotakan variabelvariabel yang diteliti, maka dilakukan penamaan faktor berdasarkan karakteristik yang sesuai dengan anggotanya. Anggota faktor ini adalah variabel fokus pada pelanggan dan pemberdayaan karyawan dengan melakukan generalisasi dari dua variabel tersebut.

Anggota faktor 1 meliputi variabel fokus pada pelanggan dan pemberdayaan karyawan. Karyawan yang didorong untuk bersikap interaktif dan ramah dalam melayani konsumen, memberikan informasi yang akurat pada konsumen, selalu mengevaluasi keluhan pelanggan, memberikan konumen kesempatan untuk menyampaikan kritik dan saran pada perusahaan serta selalu memikirkan dampak terhadap konsumen, karyawan bertanggung jawab atas seluruh tugas yang diberikan perusahaan dan selalu ada komunikasi terbuka antara karyawan dengan atasan. Dengan melakukan generalisasi dari dua variabel tersebut, faktor 1 selanjutnya dinamakan faktor kualitas pelayanan.

Anggota faktor 2 ini adalah variabel obsesi pada kualitas dan kerjasama tim, dalam memberikan pelayanan terbaik kepada konsumen. Pelayanan tersebut sesuai dengan prosedur yang berlaku, perusahaan melakukan maintenance, perbaikan dan juga pembaharuan fasilitas keseluruhan kapal secara rutin, perusahaan selalu melakukan evaluasi kerja pada karyawan, selain itu suasana kerja yang sehat dan saling memotivasi lebih baik dalam melakukan pekerjaan, serta adanya hubungan keakraban antara karyawan perusahaan. Dengan melakukan generalisasi dari kedua variabel tersebut, faktor 2 selanjutnya sebagai faktor kehandalan perusahaan.

Setelah dilakukan uji analisis faktor, maka selanjutnya dilakukan analisis regresi moderasi (Moderated Regression Analysis). Pemilihan teknik analisis MRA dalam penelitian ini menjelaskan variabel pemoderasi dalam memperkuat atau memperlemah hubungan antara variabel independen dan dependen. Dalam analisis regresi moderasi melakukan pengujian dengan regresi variabel Total Quality Management terhadap kinerja perusahaan serta interaksi Total Quality Management dengan Maintenance terhadap kinerja perusahaan bounty cruises agar mendapat nilai koefisien regresi yang ada pada masing-masing variabel menggunakan bantuan program SPSS 24. Berdasarkan hasil analisis MRA seperti yang disajikan pada tabel, maka dapat dibuat persamaan struktural sebagai berikut:

$$
\mathrm{Y}=4,021+0,545 \mathrm{X}_{1}+0,038 \mathrm{Z}_{1}+0,091\left(\mathrm{X}_{1} \cdot \mathrm{Z}_{1}\right)
$$


Tabel 7.

Rekapitulasi Hasil Analisis Regresi Moderasi

\begin{tabular}{|c|c|c|c|c|c|c|}
\hline \multirow[t]{2}{*}{ Model } & & \multicolumn{2}{|c|}{$\begin{array}{l}\text { Unstandardized } \\
\text { Coefficients }\end{array}$} & \multirow{2}{*}{$\begin{array}{l}\text { Standardized } \\
\text { Coefficients } \\
\text { Beta }\end{array}$} & \multirow[t]{2}{*}{$\mathbf{t}$} & \multirow[t]{2}{*}{ Sig. } \\
\hline & & B & $\begin{array}{l}\text { Std. } \\
\text { Error }\end{array}$ & & & \\
\hline \multirow[t]{7}{*}{1} & (Constant) & 4,021 & 0,296 & & 13,578 & 0,000 \\
\hline & $\begin{array}{l}\text { Total } \quad \text { Quality } \\
\text { Management }(\mathrm{X})\end{array}$ & ,545 & ,062 & 674 & 8,845 & ,000 \\
\hline & Maintenance $(\mathrm{Z})$ & 0,038 & 0,073 & $-0,040$ & $-0,518$ & 0,006 \\
\hline & $\mathrm{X} * \mathrm{Z}$ & 0,091 & 0,092 & 0,455 & 0,991 & 0,024 \\
\hline & Adjusted $\mathrm{R}^{2}$ & 0,443 & & & & \\
\hline & Fhitung & 26,210 & & & & \\
\hline & Sig. F & 0,000 & & & & \\
\hline
\end{tabular}

Sumber: Data diolah, 2020

Berdasarkan hasil persamaan tersebut dapat dijelaskan bahwa nilai konstanta menunjukkan bahwa bila Total Quality Management dan Maintenance tidak dilaksanakan, dengan begitu kinerja perusahaan konstan. Pada nilai koefisien regresi X sebesar $\beta_{1}$ menjelaskan bahwa bila Total Quality Management baik, maka kinerja akan meningkat. Adanya nilai koefisien regresi $\mathrm{Z}$ sebesar $\beta_{2}$ menjelaskan bahwa apabila maintenance baik, kinerja akan meningkat dengan asumsi variabel Total Quality Management (TQM) konstan. Terdapat koefisien regresi interaksi (X.Z) sebesar $\beta_{3}$ menyatakan apabila interaksi antar Total Quality Management terhadap maintenance baik, kinerja perusahaan tentu akan meningkat dengan asumsi variabel lainnya adalah konstan.

Terdapat pengujian kelayakan pada model diukur dengan hasil uji $\mathrm{F}$ dengan tingkat signifikansi $\mathrm{F}_{\text {hitung }}>$ Alpha $(\alpha=0,05)$ dalam penelitian ini nilai signifikansi sebesar 0,000 kurang dari $0,50(0,000<0,05)$ sehingga model dalam penelitian ini layak variabel independent secara simultan atau bersama berpengaruh terhadap variabel dependen. Berdasarkan data diolah, besarnya pengaruh variabel bebas terhadap variabel terikat yang ditunjukkan oleh nilai determinasi total (Adjusted $R$ Square) sebesar 0,443 mempunyai arti bahwa sebesar 44,3 persen variasi dari dimensi Total Quality Management mempengaruhi kinerja perusahaan sedangkan sisanya sebesar 55,7 persen dijelaskan oleh faktor atau variabel lain yang tidak dimasukkan ke dalam model.

Hasil $\beta_{1}$ positif $\left(\beta_{1}=0,674\right)$ signifikan (Sig. $\left.=0,000>\alpha=0,05\right)$ dan $\beta_{3}$ bernilai positif $\left(\beta_{3}=0,455\right)$ signifikan (Sig. $\left.=0,024>\alpha=0,05\right)$ mengartikan bahwa peranan moderasi yang ditunjukkan oleh variabel $\mathrm{Z}$ dapat memperkuat pengaruh $\mathrm{X}$ terhadap Y. Variabel $\mathrm{Z}$ pun dinilai sebagai variabel moderasi Moderasi Murni (pure moderator), yaitu variabel yang memoderasi hubungan antara variabel independen dan variabel dependen dalam hal ini variabel moderasi murni berinteraksi dengan variabel independen tanpa menjadi variabel independen. Terdapat beberapa penjelasan dengan melihat koefisien $\beta 1$ dan $\beta 3$ (Pradnyandari, 2019) dijelaskan Apabila $\beta 1$ positif, tidak signifikan, $\beta 3$ positif dan signifikan, maka variabel $\mathrm{Z}$ merupakan variabel moderasi yang memiliki peran memperkuat pengaruh X terhadap Y. Total Quality Management (TQM) merupakan suatu 
sistem untuk melakukan manajemen kualitas terhadap keseluruhan level operasi. Pada penelitian ini digunakan lima dimensi yaitu fokus pada pelanggan, obsesi pada kualitas, kerjasama tim, pemberdayaan karyawan, dan perbaikan berkelanjutan. Maka secara teoritis, Total Quality Management (TQM) akan dapat meningkatkan Kinerja Perusahaan Bounty Cruises.

Penelitian ini menemukan hasil koefisien regresi dari variabel Total Quality Management (TQM) sebesar 0,545, artinya Total Quality Management berpengaruh positif terhadap kinerja perusahaan dengan tingkat signifikansi 0,000 lebih besar dari $\alpha=0,05$. Hasil tersebut tentu menerima hipotesis $\mathrm{H}_{1}$ yaitu Total Quality Manajemen (TQM) berpengaruh positif terhadap kinerja perusahaan Bounty Cruises. Hal ini berarti bahwa semakin perusahaan meningkatkan kualitas pelayanan serta kehandalan perusahaan seperti fokus pada pelanggan, meningkatkan pemberdayaan kepada karyawan, obsesi terhadap kualitas, melakukan kerjasama tim, serta dengan perbaikan berkelanjutan maka akan semakin meningkatkan kinerja perusahaan, sebaliknya semakin menurun kualitas pelayanan serta kehandalan perusahaan maka akan menurunkan kinerja perusahaan. Hasil Penelitian ini sejalan dengan (Pambreni et al., 2019). Penelitian lainnya juga mnemukan bahwa Total Quality Management berpengaruh signifikan terhadap kinerja manajerial (Jannah et al., 2017). Hasil ini juga mendukung penelitian lainnya yang menyatakan bahwa elemen TQM yaitu fokus pelanggan, perbaikan berkelanjutan, strategis, dan keterlibatan total karyawan memiliki hubungan yang positif dan signifikan terhadap kinerja organisasi sektor jasa pelayanan (Bouranta et al., 2019; Pambreni et al., 2019; Reynaldo \& Pondang, 2018; Suartina, 2019).

Penelitian ini mendapatkan tanggapan positif dari responden terutama pada indikator adanya keterlibatan antar karyawan dan adanya pengawasan terhadap perbaikan berkelanjutan yang mendapatkan nilai rata-rata tertinggi. Hal ini berarti bahwa perusahaan selalu mengelola kualitasnya dengan adanya kerjasama karyawan sesuai dengan tugas dan tanggung jawabnya serta rutin melakukan pemantauan terhadap seluruh bagian kapal untuk menghindari terjadinya kerusakan pada kapal. Ketika kualitas telah dapat dijalankan dengan baik, maka kinerja perusahaan akan semakin meningkat. Sehingga hasil penelitian ini dapat memberikan kesimpulan yang sama dengan penelitian (Efendi \& Mandala, 2018) bahwa fokus pada pelanggan dan pemberdayaan karyawan merupakan dimensi dalam Total Quality Management (TQM) dapat meningkatkan kinerja Perusahaan Bounty Cruises serta salah satu faktor yang memiliki pengaruh lebih tinggi jika dibandingkan variabel lainnya dalam model penelitiannya.

Variabel Maintenance mencangkup seluruh kegiatan perawatan dalam menjamin operasional seluruh fasilitas siap difungsikan dengan baik pelayaran dan operasional dermaga. Dengan demikian, variabel ini dapat menjadi variabel yang mampu memperkuat adanya pengaruh TQM terhadap kinerja perusahaan bounty cruises. Perawatan (Maintenance) adalah variabel moderasi dengan menerapkan teknik Moderated Regression Analysis (MRA) yang mendapatkan hasil bahwa koefisiens regresi variabel interaksi yaitu 0,091 tingkat signifikan sebesar 0,024 lebih kecil dari $\alpha=0,05$ yang berarti hipotesis $\mathrm{H}_{2}$ diterima, dimana pemeliharaan/maintenance dapat memperkuat adanya pengaruh TQM terhadap 
kinerja perusahaan Bounty Cruises dengan peranan dapat memperkuat hubungan antara variabel tersebut. Penelitian diatas mendapatkan hasil yang sama dengan penelitian Putra (2020) menyebutkan maintenance sangat penting untuk dilakukan demi menjaga umur ekonomis mesin transportasi dan juga sejalan dengan penelitian yang menjelaskan bahwa adanya pengaruh yang kuat antara maintenance dengan kinerja operasional (Modgil \& Sharma, 2016).

Penelitian ini mendapatkan tanggapan positif dari responden terutama pada indikator pemeliharaan kapal dan keselamatan pekerja yang mendapatkan nilai rata-rata tertinggi. Hal ini berarti bahwa Perusahaan Bounty Cruises terus berupaya meningkatkan perawatan agar dapat memberikan layanan terbaik kepada pelanggan dan selalu mengutamakan keselamatan pekerja maka dari itu, kinerja perusahaan akan meningkat.Sehingga hasil penelitian ini dapat memberikan kesimpulan yang sama dengan penelitian (Gaudry et al., 2016) juga mendukung adanya pengaruh kuat dalam optimalisasi maintenance terhadap infrastruktur transportasi yang tentunya dalam perbaikan dan pemeliharaan dikerjakan secara profesional oleh staff pemeliharaan teknis secara berkesinambungan untuk meningkatkan kinerja perusahaan.

Hasil dari penelitian ini diharapkan dapat memberikan wawasan secara empiris terhadap ilmu manajemen operasi yang berkaitan terhadap pengaruh TQM, terhadap kinerja perusahaan. Berdasarkan hasil penelitian bahwa TQM seperti fokus pada pelanggan dan pemberdayaan karyawan, perbaikan berkelanjutan, kerjasama tim, dan obsesi terhadap kualitas memberikan pengaruh positif terhadap peningkatan kinerja perusahaan. Dari penelitian ini dapat disimpulkan bahwa penerapan dimensi TQM yang dilakukan perusahaan dengan baik, akan berpengaruh pada semakin baiknya kinerja perusahaan tersebut, karena tujuan utama dari penerapan TQM yaitu perbaikan manajemen kualitas dengan melibatkan seluruh bidang organisasi secara berkesinambungan. Selain menunjukkan adanya pengaruh TQM terhadap kinerja, penelitian ini juga menemukan peran maintenance sebagai variabel pemoderasi yang ternyata mampu memperkuat pengaruh antara TQM terhadap kinerja perusahaan pelayaran.

Penelitian ini diharapkan dapat memberikan kontribusi positif dan juga informasi kepada pihak manajemen Bounty Cruises yang dapat dijadikan sebagai salah satu bahan pertimbangan dalam pengambilan strategi perusahaan terhadap pengelolaan kualitas pada keseluruhan level operasi perusahaan. Penelitian ini dapat membuktikan bahwa maintenance turut mengambil peran penting dalam meningkatkan produktivitas kerja perusahaan pelayaran terutama pada kapal pesiar. Hal ini konsisten dan sejalan dengan teori maintenance yang mengoptimalisasikan keselamatan operator, crew, dan penumpang, memperpanjang umur pakai fasilitas, serta menjaga keefektifan fasilitas ketika dioperasikan. Pihak manajemen perlu memperhatikan prinsip-prinsip TQM lainnya selain fokus pada pelanggan dan pemberdayaan karyawan seperti memperhatikan peningkatan terhadap kerjasama tim, perbaikan berkelanjutan dan obsesi terhadap kualitas dengan tetap mengoptimalkan maintenance sesuai dengan prosedur yang distandarkan terhadap fasilitas yang ada secara rutin agar dapat mencapai kinerja yang optimal. 


\section{SIMPULAN}

Berdasarkan analisis dan pembahasan, didapatkan simpulan Total Quality Management (TQM) dapat berpengaruh positif signifikan terhadap kinerja perusahaan bounty cruises. Perusahaan dalam menerapkan dimensi Total Quality Management (TQM) dan juga penerapan maintenance yang sudah baik, maka saran yang dapat diberikan yaitu untuk meningkatkan kualitas pelayanan dan kehandalan perusahaan yang sudah baik terhadap fokus pada pelanggan dan pemberdayaan karyawan dengan memberikan pelayanan yang maksimal kepada pengunjung dan selalu bersikap interaktif dan ramah serta memberikan program pelatihan bagi karyawan.

Maintenance mampu memperkuat pengaruh TQM terhadap kinerja perusahaan Bounty Cruises. Adanya aktivitas maintenance ini antara lain berupa docking kapal setiap tahun, selain itu mengadakan perbaikan, pembersihan, pemeriksaan secara rutin, pemberian bahan bakar, menangani kerusakan dengan tepat. Walaupun pemeliharaan yang dilakukan perusahaan sudah baik, perusahaan harus meningkatkan perawatan secara prefentif agar mesin kapal selalu dalam kondisi siap pakai dan terhindar dari kerusakan yang fatal. Karena dimensi obsesi terhadap kualitas, perbaikan berkelanjutan, kerjasama tim yang dilakukan perusahaan sudah baik, perusahaan disarankan untuk lebih intens meningkatkan setiap aspek yang ada. Perusahaan dan pihak manager juga dapat menggunakan hasil penelitian ini untuk mengoptimalkan kinerja perusahaan dengan cara merancang strategi maupun kebijakan terkait dengan peningkatan maintenance, perbaikan berkelanjutan terhadap keseluruhan aset perusahaan, serta memperhatikan aspek-aspek penting lainnya yang mendukung terciptanya kinerja yang lebih baik.

Hasil penelitian ini dapat digunakan sebagai sumber acuan atau studi kasus dalam kegiatan perkuliahan. Selain itu, hasil penelitian ini dapat digunakan sebagai kajian pustaka apabila akan melakukan penelitian sejenis dengan cara meneliti kembali pengaruh dimensi-dimensi yang digunakan di dalam TQM seperti perbaikan berkelanjutan secara parsial ataupun dimensi lainya dapat dihadirkan seperti komitmen jangka panjang, pendidikan dan pelatihan yang dapat menjelaskan perubahan budaya serta pembelajaran bagi karyawan yang dapat mempengaruhi TQM sehingga hasil penelitian sesuai dengan kondisi sebenarnya. Penelitian selanjutnya dapat dilakukan untuk meneliti maintenance dalam hal Total Productive Maintenance serta service quality.

\section{REFERENSI}

Al-Damen, R. A. (2017). The impact of Total Quality Management on organizational performance Case of Jordan Oil Petroleum Company. International Journal of Business and Social Science, 8(1), 192-202.

Al-Hazmi, N. M., \& Alkhateeb, T. T. Y. (2020). Obstacles to implementing total quality management in Saudi Arabia marketing tourism Services. Management Science Letters ,10(3), 507-514. r. 
Androwis, N., Sweis, R. J., Tarhini, A., Moarefi, A., \& Hosseini Amiri, M. (2018). Total quality management practices and organizational performance in the construction chemicals companies in Jordan. Benchmarking, 25(8), 3180-3205. aksi

Au-Yong, C. P., Ali, A. S., Ahmad, F., \& Chua, S. J. L. (2017). Influences of key stakeholders' involvement in maintenance management. Property Management, 35(2), 217-231. https://doi.org/10.1108/PM-01-2016-0004

Badan Pusat Statistik Provinsi Bali. 2015. Statistik Transportasi Udara dan Laut Provinsi Bali 2014.Kota Denpasar. www.bps.go.id

. BPS Provinsi Bali. (2019). Perkembangan transportasi udara dan laut november 2018. Berita Resmi Statistik, 01(04), 1-7. www.bps.go.id

Berita Resmi Statistik Provinsi Bali No. 31/05/51/Th. VII, 4 Mei 2020 Badan Pusat Statistik. (2020) Jumlah Penumpang Transportasi Laut Bali. www.bps.go.id

Bouranta, N., Psomas, E., Suárez-Barraza, M. F., \& Jaca, C. (2019). The key factors of total quality management in the service sector: a cross-cultural study. Benchmarking, 26(3), 893-921. https://doi.org/10.1108/BIJ-09-20170240

Efendi, P., \& Mandala, K. (2018). Pengaruh Implementasi Total Quality Management Terhadap Kepuasan Pelanggan Pada Perusahaan Barjaz Di Denpasar. E-Jurnal Manajemen Universitas Udayana, 7(3), 1653. https://doi.org/10.24843/ejmunud.2018.v7.i03.p19

Fachrurozi, A.F., (2018) Skripsi Implementasi Total Quality Management (Tqm) Terhadap Kualitas Pelayanan Di Pt. Mitrabuana Citra Abadi (Ford Jogja).

Famurewa, S. M., Asplund, M., Rantatalo, M., Parida, A., \& Kumar, U. (2015). Maintenance analysis for continuous improvement of railway infrastructure performance. Structure and Infrastructure Engineering, 11(7), 957-969. https://doi.org/10.1080/15732479.2014.921929

Firmanzah, A., Hamid, D., \& Djudi, M. (2017). PENGARUH KESELAMATAN DAN KESEHATAN KERJA TERHADAP KINERJA KARYAWAN (Studi Pada Karyawan PT. PLN (Persero) Area Kediri Distribusi Jawa Timur). Jurnal Administrasi Bisnis S1 Universitas Brawijaya, 42(2), 1-9.

Gaudry, M., Lapeyre, B., \& Quinet, É. (2016). Infrastructure maintenance, regeneration and service quality economics: A rail example. Transportation Research Part B: Methodological, 86, 181-210. https://doi.org/10.1016/j.trb.2016.01.015 
Gifari, Mahardhito. (2017). Hubungan Delay Karena Penanganan Flight Operation dan Teknik dengan On Time Performance pada Maskapai Penerbangan NAM Air di Bandar Soekarno-Hatta. Skripsi. Sekolah Tinggi Manajemen Transportasi Trisakti. Jakarta.

Handoko, T. Hani. 2009. Manajemen. Yogyakarta: BPFE-Yogyakarta.

Harimurti, R., \& Suryani, T. (2019). the Impact of Total Quality Management on Service Quality, Customer Engagement, and Customer Loyalty in Banking.

Heizer Jay., \& Render, Barry. (2015). Manajemen Operasi: Manajemen Keberlangsungan dan Rantai Pasokan, Edisi Kesebelas. Jakarta: Salemba Empat.Hendayani, R. (2015). Analisis Implementasi Total Quality Management ( Tqm ) Dan. (October).

Hidayat, S., 2018. Model Pengembangan Pramuwisata Olahraga dalam Bisnis Pariwisata di Provinsi Bali. JURNAL PENJAKORA, 5(1), pp.8-16.

Husna, A. J. (2015). Penerapan Model Maintenance Quality Function Deployment Untuk Meningkatkan Kualitas Pemeliharaan Mesin Allwin Pada Cv. Isillo. m http://repository.ekuitas.ac.id/handle/123456789/260

Jannah, A. W., Fauziah, N. E., \& Abdurrahman, D. (n.d.). Analisis Pengaruh Total Quality Management ( TQM) Terhadap Kinerja Manajerial di Bank BRI Syariah KCI Citarum Bandung. 472-478.

Kotler, Philip dan Kevin Lane Keller. 2009. Manajemen Pemasaran. Alih bahasa oleh Jurnal Administrasi Bisnis (JAB)|Vol. 46 No.2 Mei 2017| administrasibisnis.studentjournal.ub.ac.id 53 Bob Sabran.Edisi 13. Jilid 1. Jakarta:Penerbit Erlangga.

Maharani, I.A.R. and Budiasih, I.G.A.N., (2018) Penerapan Balanced Scorecard Sebagai Pengukuran Kinerja Perusahaan (PT. Gde Kadek Brothers Layar Antarnusa-Bounty Cruises). E-Jurnal Akuntansi, pp.635-666. https://ojs.unud.ac.id/index.php

Malamansyah, L.E., 2016. Pengaruh Total Quality Management terhadap Peningkatan Laba Perusahaan ada PT Pos Indonesia (Doctoral dissertation, Fakultas Ekonomi dan Bisnis (UNISBA).

Modgil, S., \& Sharma, S. (2016). Total productive maintenance, total quality management and operational performance An empirical study of Indian pharmaceutical industry. Journal of Quality in Maintenance Engineering, 22(4), 353-377. https://doi.org/10.1108/JQME-10-2015-0048 
Palandeng, Indrie Debbie, Gaspar Enjelina Chintia, P. J. J. (2019). Pengaruh Total Quality Management ( Tqm ) Terhadap Kualitas Layanan Pada Pt . Pln ( Persero ) Area Manado The Effect Of Total Quality Management On Service Quality In Pt . Pln ( Persero ) Area Manado. Jurnal EMBA, 7(4), 5860-5869.

Pambreni, Y., Khatibi, A., Ferdous Azam, S. M., \& Tham, J. (2019). The influence of total quality management toward organization performance. Management Science Letters, 9(9), 1397-1406. https://doi.org/10.5267/j.msl.2019.5.011

Pradnyandari, T. S. (2019). Peran Maintenance Dalam Memoderasi Pengaruh Scheduling Terhadap Kinerja Maskapai Penerbangan ( Studi Pada Garuda Indonesia Airline ) Fakultas Ekonomi dan Bisnis Universitas Udayana, Bali , Indonesia. 8(6), 3473-3501.

Putra, G.M.P. and Irawan, A., (2020). Analisis Pemeliharaan Preventif Ac Package Pada Gerbong Kereta Penumpang K1 Di Depo 2 Gerbong Kereta Bandung. Gema: Jurnal Gentiaras Manajemen dan Akuntansi, 12(1), pp.4859.

Reynaldo, L. O., \& Pondang, J. J. (2018). Analisis Pengaruh Total Quality Management Terhadap Kinerja Manajerial Pada Pt. Angkasa Pura 1 (Persero) Bandar Udara International Sam Ratulangi Manado. 6(3), 14581467.

Schepers, J., \& Nijssen, E. J. (2018). Brand advocacy in the frontline: how does it affect customer satisfaction? Journal of Service Management, 29(2), 230252. https://doi.org/10.1108/JOSM-07-2017-0165

Suartina, I. W. (2019). I Wayan Suartina Pengaruh Total Quality .... 1(2), 1-20.

Widjaya, O. E. Y. H., \& Suryawan, I. N. (2014). Pengaruh Total Quality Management dan Quality Management Information Terhadap Kinerja Perusahaan. Media Bisnis, 6(2), 88-96.

Yuliana dina. (2017). Jurnal Perhubungan Udara Penumpang Di Bandara Husein Sastranegara Bandung The Influence of Facility, Service and Accessibility Information on Passenger Satisfaction Level at Husein Sastranegara Airport - Bandung. WARTA ARDHIA Jurnal Perhubungan Udara, 43, 27-42. https://wartaardhia.com/index.php/wartaardhia/article/view/235/pdf 